\title{
In memoria di Franco Calvetti
}

Federico Perotto

\section{(2) OpenEdition}

\section{Journals}

Edizione digitale

URL: http://journals.openedition.org/esp/2095

DOI: 10.4000/esp.2095

ISSN: 2532-0319

\section{Editore}

Centre d'Information sur l'Éducation Bilingue et Plurilingue

\section{Edizione cartacea}

Data di pubblicazione: 1 giugno 2018

Paginazione: 5-8

ISSN: 1127-266X

\section{Notizia bibliografica digitale}

Federico Perotto, « In memoria di Franco Calvetti », Éducation et sociétés plurilingues [Online], 44 | 2018,

Messo online il 08 février 2019, consultato il 24 septembre 2020. URL : http://

journals.openedition.org/esp/2095; DOI : https://doi.org/10.4000/esp.2095 


\section{IN MEMORIA DI FRANCO CALVETTI}

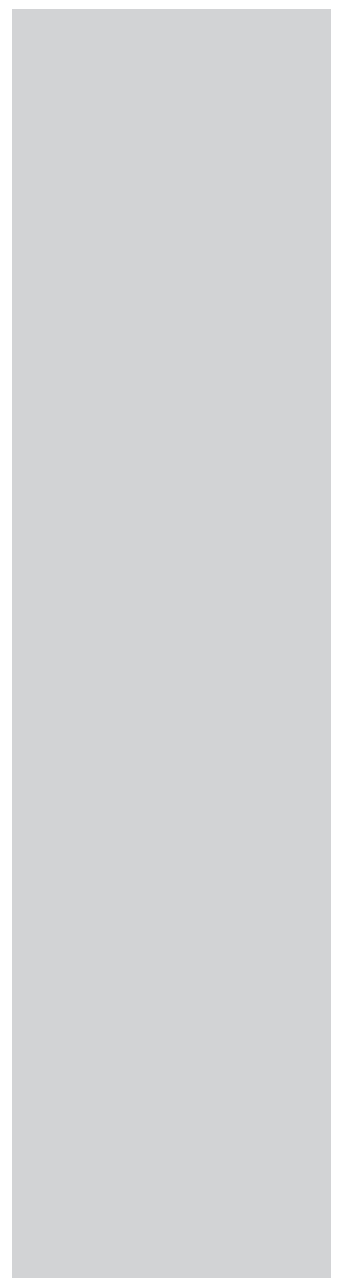

\section{Federico Perotto}

Mots-clés: Franco Calvetti, pédagogue, linguiste, Pinerolo, Association nationale italienne des directeurs d'école, ANDIS

Key-words: Franco Calvetti, educator, linguist, Pinerolo, Italian Association of School Directors, ANDIS

"La lingua è il veicolo attraverso cui passano i valori della comunità che la parla."

Passando in rassegna la documentazione raccolta da Franco in decine di raccoglitori e faldoni attraverso decenni di lavoro, colgo fra i suoi appunti di fine anni Ottanta questa singola frase come paradigma dell'opera di una vita.

Franco Luigi Calvetti è nato l'otto di giugno del 1939 a Perosa Argentina, nelle valli del Pinerolese, ed è recentemente mancato dopo avere trascorso gli ultimi anni tra Pinerolo e la Penisola Sorrentina.

Bilingue perfetto italiano/francese, a questa combinazione e a tutto il suo intorno, a $360^{\circ}$, ha dedicato gran parte della sua esistenza. Già dirigente scolastico, fiero Valdese e al contempo sostenitore della laicità, eminente linguista, noto pedagogo e sostenitore dell'insegnamento precoce delle lingue straniere, è stato segretario generale del CIEPB (Centro di Informazione sulla Educazione Bilingue e Plurilingue) di cui è in seguito diventato membro d'onore.

Nel 1988 è stato insignito del titolo di Cavaliere delle Palme Accademiche Francesi dal Ministro dell'Istruzione Nazionale Lionel Jospin; nel 1995 gli è stata conferita l'onorificenza di Ufficiale al Merito della Repubblica Italiana.

Cofondatore dell'Associazione Nazionale dei Dirigenti Scolastici ANDIS, presidente per due mandati della Croce Verde di Perosa Argentina, ha fatto parte per molti anni del Comitato Scientifico della rivista École e dell' Istituto per l'Ambiente e l'Educazione Scholè Futuro dedicando grande passione alle tematiche ambientali. 
In memoria di Franco Calvetti F. Perotto
Ha collaborato a riviste e periodici di cultura e d'arte, e ha pubblicato numerosi libri per l'infanzia, due raccolte di poesie e un libro di ricordi d'infanzia "Da bambini... Il coprifuoco". L'ultima sua opera pubblicata è "aColuicheè", una raccolta di intime preghiere.

Lo conobbi ad Asti, nel luglio del '99, durante una conferenza di Henriette Walter nell'ambito dell'università estiva "L'école du voisin": accompagnavo la moderatrice Catherine Petillon, direttrice del Centre Culturel Français di Torino, al tempo non ero altro che uno spiantato laureando in linguistica. Giunsi in ritardo, i due posti liberi rimasti erano occupati da "riservato alle autorità", ma osai sedermi in uno di questi, casualmente di fianco a lui.

Fu molto divertito da tale evidente occupazione indebita, e subito mi chiese: "Scusi, lei è un'autorità?." "Ovviamente!" gli risposi, e la fragorosa risata che seguì in coro sancì simpatia a prima vista.

La rottura degli schemi precostituiti, la ribellione alle imposizioni, quelle sì, indebite; l'opposizione radicata dalle sue valli nel suo sangue ad ogni tipo di fascismo e discriminazione, il tutto inserito in quel che Fabrizio De André avrebbe riconosciuto come "Rigorosa anarchia interiore", seppur illuminata dal Dio in cui credeva... Ecco un altro importante lato di Franco, ribelle per principio.

La docenza in Africa, la continua ricerca pedagogica, decenni dedicati all'insegnamento sul campo, sempre ispirati dal suo credo "Tutti uguali e sempre con gli ultimi".

Nel 1975, rientrato in Italia si è dedicato con grande passione all'insegnamento nel Circolo Didattico "Casalegno" di Torino promuovendo, con l'allora Direttore Enrico Cavallero ed un gruppo di docenti, una metodologia di insegnamento basata sul principio delle classi aperte, team teaching, sistema di laboratori volta a far emergere $\mathrm{i}$ talenti anche degli allievi più in difficoltà, non lasciando mai nessuno in disparte.

Con la sua naturale capacità di raccontare e descrivere riusciva a coinvolgere ed attirare l'attenzione di tutti gli allievi, e con la sua splendida voce insegnava loro canzoni in varie lingue.

Dopo avere superato il concorso direttivo, diviene dirigente scolastico del circolo "C. Collodi" di Torino ed in seguito di Perosa Argentina, fino al pensionamento.

Per chi scrive è stato per anni Zio Franco, amico, mentore e guida nel mondo della ricerca linguistica che ha sempre creduto in me introducendomi al CIEBP e trasmettendomi l'interesse per l'insegnamento, oltre che costituire un grande esempio di libero pensiero e creatività. 
In memoria di Franco Calvetti F. Perotto
Prima indebolito e poi abbattuto da una serie di gravi malanni, si è arreso nella notte fra il 27 e il 28 dicembre scorso dopo una lunga guerra contro la malattia, sempre ammirevolmente sostenuto, aiutato e amato dal suo straordinario compagno Urgen, con una cura, un'attenzione e un affetto che mai ho avuto modo di osservare in alcun'altra persona.

Ringraziando Margherita Bersisa, amica e collega di Franco, per i contributi sul suo lato accademico... Ci mancherà.

Franco Luigi Calvetti est né le 8 juin 1939, à Perosa Argentina, dans les vallées de Pinerolo (Turin, Italie). Il nous a quittés récemment (27 déc. 2017) après avoir passé ses dernières années entre Pinerolo et la péninsule de Sorrento.

Anciennement professeur principal, fier Vaudois et en même temps défenseur de la laicité, linguiste éminent, pédagogue bien connu et champion de l'éducation bilingue, il fut pendant des années le secrétaire général du CIEBP, puis correspondant et membre d'honneur.

En 1988 le ministre français de l'Éducation Nationale Lionel Jospin lui décerna les Palmes Académiques et en 1995 il fut nommé Officier du Mérite de la République italienne.

Co-fondateur de l'Association nationale italienne des directeurs d'école ANDIS, président pendant deux mandats de la Croix Verte de Perosa Argentina, il fut membre du comité scientifique de la revue École et de l'Institut pour l'environnement et Éducation Scholè Futuro.

Il collabora à des publications d'art et de culture et publia plusieurs ouvrages pour enfants, deux recueils de poèmes et un livre de souvenirs d'enfance. Sa dernière publication est "aColuichee", une collection de prières intimes. 
In memoria di Franco Calvetti F. Perotto
Franco Luigi Calvetti was born on June 8 1939, in Perosa Argentina, in the valleys of the Pinerolo area (Turin, Italy). He recently passed away (Dec. 27, 2017) after spending his last years between Pinerolo and the Sorrento Peninsula.

Former head teacher, proud Waldensian and at the same time supporter of secularism, eminent linguist, well-known pedagogue and champion of the early teaching of foreign languages, he was for years secretary general of the CIEPB of which he later became a member of honor.

In 1988 he was awarded the title of Knight of the French Academic Palms by the French Minister of Éducation Lionel Jospin; in 1995 he was conferred the honor of Officer of Merit of the Italian Republic.

Co-founder of the Italian National Association of School Directors ANDIS, president for two terms of the Green Cross of Perosa Argentina, he has been a member of the Scientific Committee of the École magazine and of the Institute for the Environment and Education Scholè Futuro.

He collaborated in magazines focused on culture and art, and published numerous books for children, two collections of poetry and a book of childhood memories. His last published work is "aColuichee", a collection of intimate prayers. 